\title{
Effects of global warming on Asian lakes from viewpoints of water resources and environmental change
}

\author{
H Fushimi \\ The University of Shiga Prefecture, School of Environmental Science, 2400 Hassakacho, Hikone 522-8533 JAPAN \\ For correspondence, E-mail: fushimi@ses.usp.ac.jp
}

\begin{abstract}
Lakes in the Himalayas and Tibetan plateau
Due to the global warming, the recent fluctuations of glaciers and lakes in the Nepal and Bhutan Himalayas are extremely immense and the region faces more natural disasters including the glacial lake outburst flood. There is a need to create a new management system for the rational use of water resources taking into account the recent changes in glacial as well as limnological phenomena.

The Himalayas and Tibetan plateau will face the shortage of glacier-fed water resources due to the shrinkage of glacier as well as permafrost ice bodies in the late period of the 21st century, and the decrease in glacial melt-water will tend to exacerbate drought phenomena in the catchment areas of the mighty rivers, such as Rivers Yellow, Yangtze, Mekong, Ganges and Indus, especially during the dry season in areas with the rapid population growth dependent on water resources from the glaciers and permafrost layers in the Himalayas and Tibetan plateau.
\end{abstract}

\section{Lake Hovsgol in Mongolia}

The water level of Lake Hovsgol in Mongolia has risen $60 \mathrm{~cm}$ during the past 20 years, so that the surrounding forests, pastures and the lakeshore town have been inundating year by year. Three causes of the water level rise could be noticed as follows: 1) the formation of a natural dam at the southern end of the lake caused by the sedimentation of sand and gravel which were transported from the tributary river at the time of heavy rain, 2) the thaw of permafrost around the lake where the ground temperature becomes higher with increases of the incoming radiation due to deforestation owing to the anthropogenic expansion of pasturage and forest fire, and 3) the thaw of permafrost caused by the global warming.
Here, we would like to suggest as the short-term countermeasure that the natural dam should be dredged to prevent the inundation, because it can be estimated to lower 30 $\mathrm{cm}$ of the water level by the dredging of only $500 \mathrm{~m}^{3}$. As the midterm countermove, it is important to improve the anthropogenic land-use for preventing the expansion of pasturage and forest fire. Finally, as the long-term issue, we hope to solve the global warming with the international cooperation by monitoring the natural environmental changes of Lake Hovsgol.

Lake Biwa in J apan

It is reported that an average air temperature will increase by 1.5 to 3.5 degrees Celsius by the 2030's due to the global warming. If the increase in average air temperature is 1.5 degrees Celsius, the amount of snow cover would not exceed 1 billion tons, which is the average amount of snow cover in Lake Biwa basin, unless the precipitation exceeds more than $20 \%$. When the average air temperature rises by 3.5 degrees Celsius, the amount of snow cover would significantly decrease to 0.6 billion tons even if the precipitation exceeds by $20 \%$.

When the amount of snow cover is more than 1 billion tons, the lowest dissolved oxygen concentration in the deep layer of Lake Biwa increases due to the density current of the oxygenrich snowmelt. However, the dissolved oxygen concentration rapidly decreases, when the amount of snow cover is less than 1 billion tons. The global warming will significantly decrease the amount of snow cover in Lake Biwa basin and the dissolved oxygen concentration in the deep layer of the lake, so it leads to further enhancement of eutrophication in the $21^{\text {st }}$ century. 